\title{
Facts and Comparisons: Journal Updates and Performance Indicators
}

\author{
Mary H H Ensom
}

In January 2006, the CJHP Editorial Board, as well as 1 members of CSHP Council and staff, selected individuals from the Society's general membership (including students), and representatives of both the CSHP Research and Education Foundation and the American Journal of Health-System Pharmacy participated in a day-long strategic businessplanning session for the CJHP. In conjunction with an environmental scan, for which we received input from other stakeholders, this planning session culminated in a 6-year strategic business plan with the purpose of serving as both a compass and a road map for the Journal. ${ }^{1}$

Four years later, in January 2010, the CJHP Editorial Board held another strategic planning meeting with the CSHP Executive and staff members to review progress and discuss a long-term vision for the Journal.

\section{PROGRESS}

During the past few years, several visible enhancements have been made to the Journal:

- April 2007: Launch of CJHP's Web-based submission and peer review system, hosted by eJournalPress (eJPress) (http://CJHP.msubmit.net/cgi-bin/main.plex).

- January 2008: Increase in annual number of issues from 5 to 6.

- April 2009: Launch of CJHP's online hosting platform (www.CJHP-online.ca/index.php/CJHP), which uses the Public Knowledge Project's publishing system, Open Journal Systems, with website design, article uploading, and technical support provided by Multimed Inc. CJHP Online is intuitive, easy to use, and fully searchable. A complete archive of issues from 2003 to April 2009 was available on launch day, and the issues for 2000 to 2002 were added by the end of May 2009. The CJHP Editorial Board has received much positive feedback about the online CJHP. In recognition of the need to

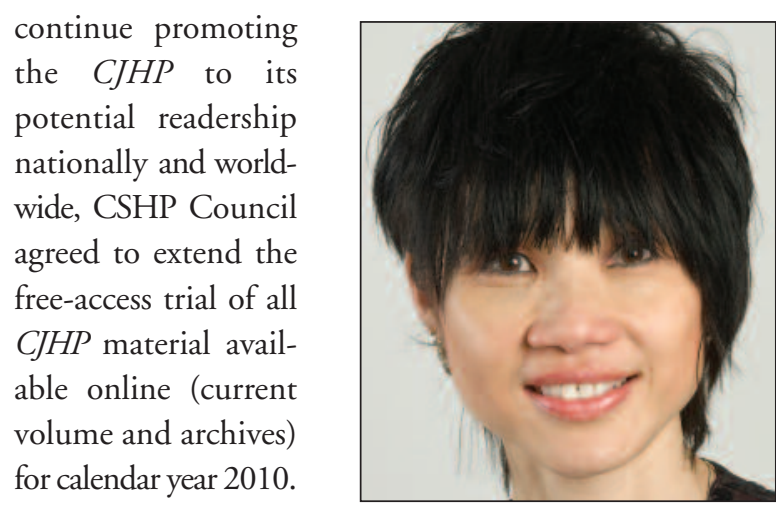

- March 2010: Archiving of CJHP in PubMed Central (www.ncbi.nlm. nih.gov/pmc/journals/1115/). We received the exciting news in fall 2009 that the CJHP had been successful in its application to be archived in PubMed Central, the US National Institutes of Health's free digital archive of biomedical and life sciences journal literature! As of March 2010, all issues from January-February 2009 to the present are listed in PubMed Central. Editorials, Reports from the Presidential Team, and Society News items are available immediately, and scientific content becomes available 24 months after publication.

The members of the Editorial Board would also like to share with you, our readers, some of the CJHP's objective performance indicators. Table 1 summarizes data for articles published from 2005/2006 to 2009/2010. With the launch of eJPress, it became possible to track various statistics for submitted manuscripts, and Table 2 summarizes, for the period 2007 to 2010, data for the peer-reviewed articles in $C J H P$, specifically number of submitted manuscripts, acceptance rate, and average turnaround times from submission to initial decision and from submission to final decision. Both of these tables demonstrate that the performance of the Journal is progressing in a positive direction. 
Year*; No. of Articles or Pages

\begin{tabular}{|c|c|c|c|c|c|}
\hline & $2005 / 2006$ & $2006 / 2007$ & $2007 / 2008$ & $2008 / 2009$ & $2009 / 2010$ \\
\hline \multicolumn{6}{|l|}{ No. of articles by section } \\
\hline Articlest & 13 & 17 & 17 & 24 & 30 \\
\hline Case Reports & 3 & 3 & 5 & 1 & 3 \\
\hline Pharmacy Practice & 6 & 2 & 5 & 5 & 8 \\
\hline Practice Spotlightł & NA & 4 & 5 & 6 & 6 \\
\hline Drug Information Notes & 0 & 0 & 0 & 0 & 1 \\
\hline Safe Medication Practices & NA & 5 & 5 & 6 & 3 \\
\hline Point Counterpoint‡ & NA & 2 & 5 & 6 & 6 \\
\hline Books and Other Media (reviews) & 6 & 0 & 4 & 14 & 13 \\
\hline Letters & 7 & 5 & 6 & 7 & 7 \\
\hline Society News§ & NA & NA & 4 & 2 & 1 \\
\hline \multicolumn{6}{|l|}{ No. of pages, by type of material } \\
\hline Advertising & 99 & 87 & 52 & 109 & 74 \\
\hline Articles and other content & 220 & 273 & 340 & 4081 & 4629 \\
\hline Total & 319 & 360 & 392 & 517 & 536 \\
\hline Ad ratio** & 0.31 & 0.24 & 0.13 & 0.21 & 0.14 \\
\hline Issues published & 5 & 5 & 5 & 6 & 6 \\
\hline
\end{tabular}

NA = not applicable.

*Twelve-month period from July 1 to June 30.

tResearch articles and reviews.

¥Section initiated in 2006/2007.

$\S$ Full articles only (the publication of full articles in the Society News section was initiated in 2006/2007).

IDoes not include supplementary "online-only" pages.

$\star *$ Number of advertising pages $\div$ total number of pages published.

\section{LONG-TERM VISION}

Much of the 2010 strategic planning meeting was spent discussing our long-term vision for the CJHP. We began by trying to define where the $C J H P$ is going and to identify how we can best make the transition. We discussed the number of issues to be published each year, the potential move to permanent open access and "online-only" publication, and possible implications for expenses and revenues.

Regarding open access, both PubMed Central and the National Institutes of Health strongly encourage journals to make their content accessible to the public (via PubMed Central), no later than 12 months after publication (http://publicaccess.nih.gov/), but preferably immediately. Most researchers and authors prefer to have their work available in open access format right away, so that they can reach a global audience. It is argued that scholarship builds on the work that precedes it and that robust research and scientific development depend on readily accessible sources that allow for the development of new ideas. In addition, scientific bodies and funding organizations are now mandating (or encouraging) all funding recipients to make their papers freely accessible immediately after publication. Although concern was raised during our strategic planning session that the CJHP is viewed as a tangible benefit of CSHP membership and that making it "freely available" might diminish this benefit, the Editorial Board's response to this concern focused on the immediate and positive impact that open access would have on the quality of the Journal (by encouraging more and better submissions and by allowing the Journal to have a more immediate global impact). Providing CSHP members with a better-quality Journal would be a positive move, even if the Journal itself would no longer be an exclusive member benefit.

Regarding the availability of the Journal in "online-only" form, nearly half of respondents to the 2009 CSHP Membership Survey indicated that they would prefer to receive the CJHP in this format exclusively. Although the march of technological advancement makes me believe that eventually all journals will be online only, most journals today are available both in print and online. The most likely reasons for continuing to publish a print version are the anticipated loss of advertising revenue and perhaps a perceived loss of prestige with online-only publication.

Because of uncertainty about the impact of open access and online-only publication on CJHP revenues, CSHP Council, during its 2010 Midterm Meeting, postponed a decision on the CJHP Editorial Board's recommendations that the full texts of all $C J H P$ articles continue to be open access immediately and permanently and that the CJHP be published online only (beginning in January 2011). These recommendations will be revisited when Council meets 
Table 2. Other CJHP Performance Indicators

\begin{tabular}{|c|c|c|c|c|}
\hline \multirow[b]{2}{*}{ Manuscript Type* } & \multirow[b]{2}{*}{$\begin{array}{l}\text { No. of Manuscripts } \\
\text { Submitted }\end{array}$} & \multirow[b]{2}{*}{$\begin{array}{l}\text { Acceptance } \\
\text { Rate (\%) }\end{array}$} & \multicolumn{2}{|c|}{ Decision Interval (Days) } \\
\hline & & & $\begin{array}{c}\text { Receipt to } \\
\text { First Decision }\end{array}$ & $\begin{array}{c}\text { Receipt to } \\
\text { Final Decision }\end{array}$ \\
\hline \multicolumn{5}{|c|}{2007 (April to December) } \\
\hline Case Reports & 4 & 75 & 57.0 & 94.5 \\
\hline Drug Information Notes & 1 & 0 & 108.0 & 148.0 \\
\hline Pharmacy Practice & 5 & 60 & 85.6 & 128.6 \\
\hline Research reports & 23 & 65 & 102.9 & 213.7 \\
\hline \multicolumn{5}{|l|}{ Calendar year 2008} \\
\hline Case Reports & 2 & 100 & 4.0 & 55.0 \\
\hline Drug Information Notes & 1 & 0 & 46.0 & 46.0 \\
\hline Literature reviews & 5 & 100 & 74.2 & 204.0 \\
\hline Pharmacy Practice & 7 & 57 & 78.7 & 142.1 \\
\hline Research reports & 40 & 73 & 79.8 & 143.4 \\
\hline \multicolumn{5}{|l|}{ Calendar year 2009} \\
\hline Case Reports & 7 & 83 & 54.0 & 133.8 \\
\hline Drug Information Notes & 1 & 100 & 54.0 & 106.0 \\
\hline Literature reviews & 2 & 50 & 59.5 & NA \\
\hline Pharmacy Practice & 14 & 57 & 64.2 & 102.3 \\
\hline Research reports & 29 & 62 & 64.5 & 102.3 \\
\hline \multicolumn{5}{|l|}{2010 (January to April) } \\
\hline Case Reports & 1 & NA & NA & NA \\
\hline Literature reviews & 2 & NA & 54.0 & NA \\
\hline Pharmacy Practice & 5 & NA & NA & NA \\
\hline Research reports & 7 & NA & 57.7 & NA \\
\hline
\end{tabular}

$\mathrm{NA}=$ not available.

*Does not include manuscript types that typically do not undergo external peer review (book reviews, editorials, letters to the editor, submissions for Point Counterpoint column, and articles in Practice Spotlight section).

before the 2010 Summer Educational Sessions. The CJHP Associate Editors and I remain hopeful that the CJHP's vision of being "an academic journal that focuses on how Canadian pharmacists optimize safe and effective drug use in patients" will be fully realized and that the Journal will be freely accessible to readers around the world in the near future!

\section{Reference}

1. Ensom MHH. A motivational letter [editorial]. Can J Hosp Pharm 2006;59(2):61-62

Mary H H Ensom, PharmD, FASHP, FCCP, FCSHP, FCAHS, is Professor and Director, Doctor of Pharmacy Program, Faculty of Pharmaceutical Sciences, and Distinguished University Scholar, The University of British Columbia, and Clinical Pharmacy Specialist, Children's \& Women's Health Centre of British Columbia, Vancouver, British Columbia. She is also Editor of the CJHP.

\section{Address correspondence to:}

Dr Mary $\mathrm{H} \mathrm{H}$ Ensom

Department of Pharmacy (OB7)

Children's \& Women's Health Centre of British Columbia

4500 Oak Street

Vancouver BC V6B 6E4

e-mail: ensom@interchange.ubc.ca

\section{Acknowledgement}

I would like to acknowledge the invaluable assistance of Sonya Long and Colleen Drake in preparing this editorial.

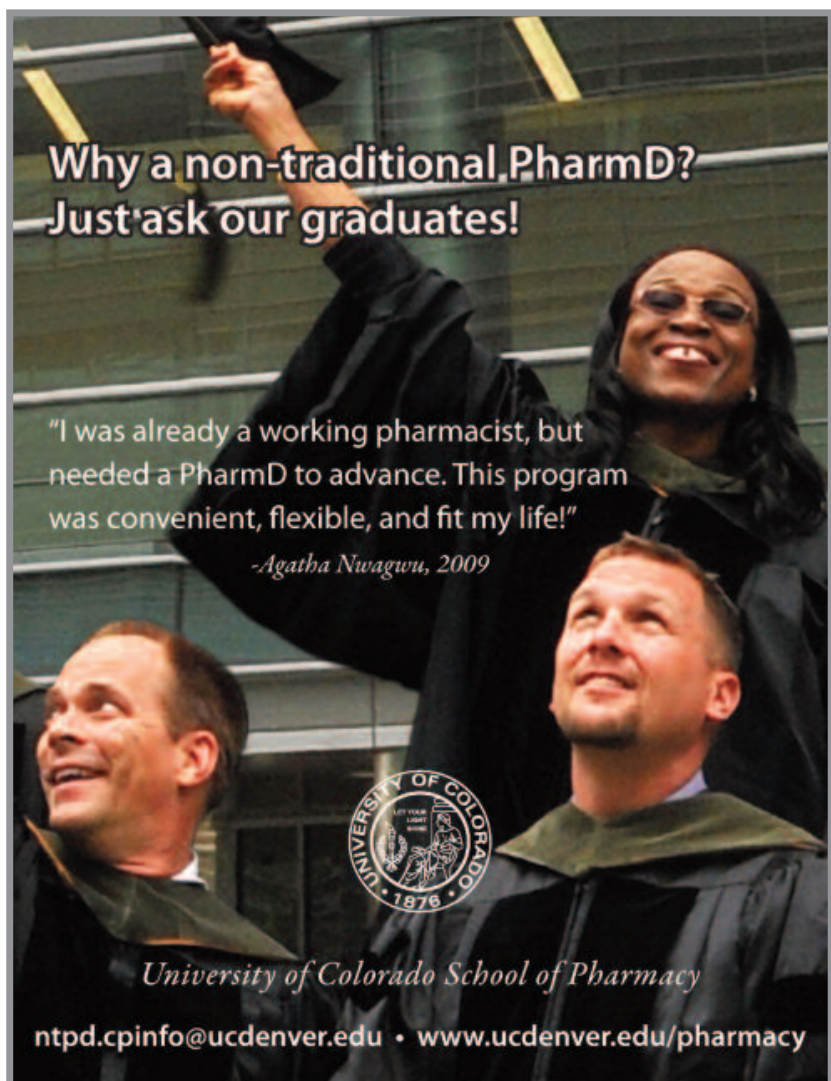

